Available Online at http://journal.unismuh.ac.id/index.php/otoritas

Otoritas : Jurnal Ilmu Pemerintahan, 8 (1), April 2018, 44-55

\title{
Sustainable Development Goals (SDGs) and Indonesian Housing Policy
}

\author{
Saddam Rassanjani*) \\ School of Social and Political Sciences, University of Glasgow, Glasgow, G12 8QQ, \\ Scotland, United Kingdom.
}

Received: 7 July 2017; Revised: 29 March 2018; Accepted: 1 April 2018

\begin{abstract}
The main objective of the implementation of Sustainable Development Goals (SDGs) in Indonesia is to bring accelerated development in all aspects so that the poverty rate is expected to decrease even disappear. One of the programs that aimed to reduce poverty rates in Indonesia is the provision of housing for the community, especially the underprivileged. Moreover, it is a the million houses program that proclaimed by the Ministry of Public Works and People's Housing, and this program is correlated with the SDGS, especially goal 11: sustainable cities and communities. The research is relying on secondary data basis primarily from books, journals, published reports and online news. It is expected that this study is able to provide a new insight for the government in building a community residential area, which is to integrate development plans into three dimensions (social, economic, and environment) which are the pillars of sustainable development. Unfortunately, nowadays the government is relying too hard on achieving quantity and a little focus on quality. Furthermore, an experience on the MDGs edition can be an important lesson for the government in realizing SDGs, especially now that SDGs are in line with the points that contained in the RPJMN. Therefore, if the government is able to maximise this global development agenda, it is not impossible that the million houses program can be one of the leading programs in overcoming the problem of poverty, especially housing shortage in Indonesia.
\end{abstract}

Keywords: Indonesia, SDGs, MDGs, Housing, The Million Houses

How to Cite: Rassanjani, S. (2018). Sustainable Development Goals (SDGs) and Indonesian Housing Policy. Otoritas : Jurnal Ilmu Pemerintahan, 8(1), 44-55.

Permalink/DOI: https://doi.org/10.26618/ojip.v8i1.760

${ }^{*}$ Corresponding Author.

E-Mail : sany.arrahman@gmail.com

Copyright (C) 2018, Otoritas : Jurnal Ilmu Pemerintahan, ISSN: 2088-3706 (Print), ISSN: 2502-9320 (Online) 
Available Online at http://journal.unismuh.ac.id/index.php/otoritas

Otoritas : Jurnal Ilmu Pemerintahan, 8 (1), April, 2018, 45

\section{INTRODUCTION}

Sustainable Development Goals (SDGs) is a global policy initiated by the United Nations (UN) to be applied locally by the members in order to end an extreme poverty for the realisation of sustainable development (UN, 2015). As this program aims to eradicate poverty, it is expected that presence of the SDGs is able to help the acceleration of the development in all aspects in developing countries, including Indonesia.

SDGs is a form of refinement of the Millennium Development Goals (MDGs) which have broader objectives (17 goals) than MDGs (8 Goals). In more details, SDGs offers a broad goal, including; involve more countries both developed and developing countries, expanding sources of funding, emphasis on human rights, inclusive, the involvement of civil society, the completion target of a more progressive, and load the ways of implementation (Bappenas, 2016). Furthermore, Kumar et. al. (2016) said that the SDGs reflect the increasing consolidation of the convergence of the international development agenda, and to strengthen the equity, human rights, and non-discrimination. However, it could not be stated yet that the SDGs will be more successful than the MDGs, but indeed the presence of SDGs cover up the weaknesses of MDGs.

There are 17 goals and 169 targets that included into SDGs documents (UN, 2015), including ten targets that related to sustainable housing development. Moreover, the accomplishment target that contained in SDGs documents has been included in Indonesian development priorities, and to achieve them, the government realise that it is necessary to synergies policies planning at the national level and also local government. Thus, the targets of SDGs have been in line with the Rencana Pembangunan Jangka Menengah Nasional (RPJMN) 2015-2019 at the national level, and it has been structured in the form of programs, indicators, and indications of funding support.

Housing and its problem are one of SDGs resolution, as it is mentioned in Goal 11 (sustainable cities and communities). However, it is lack of research in Indonesia that focused on SDGs and housing matters deeply. Susanti et. al. (2016) correlated the sustainable issues in the smart city and residential density topic but did not argue the SDGs in the discussion. Moreover, Lubis and Sinaga (2018) promoted the SDGs in the opening of discussion, but the research is focused on helping the low-income families to access the affordable house by using the implementation of philanthropy-related regulations. Therefore, this research will examine the implementation of SDGs in Indonesia and it's housing program, with the hope that this research can generate a new insight for the government in building public housing, which is to build a house by promoting the concept of sustainability.

The discussion will be divided into three sub-discussion, first of all, the transformation and comparison of MDGs and SDGs. Secondly, what is the action plan that taken by the Indonesian government to succeed the SDGs in 2030? And lastly, it will be a focus on Goal 11, especially housing program named a million houses which implemented to tackle the housing shortages toward to end the social and economic problems (zero goals).

\section{RESEARCH METHODS}

This paper is a qualitative study that utilises secondary data as the main research analysis. Andrews, et.al. (2012) stated secondary data analysis as one of the research strategies that utilise a quantitative or qualitative data set that has been available, and the data is used to reveal new problems or test the results of previous research. Meanwhile, Johnston (2014) argued that secondary data analysis as a research technique which is rarely 
Available Online at http://journal.unismuh.ac.id/index.php/otoritas

Otoritas : Jurnal Ilmu Pemerintahan, 8 (1), April, 2018, 46

used in various fields, despite that this technique is known as a systematic method of research.

\section{RESULTS AND DISCUSSION}

The presence of a global agenda is able to provide a new insight into a country in carrying out its development. Starting from Millennium Development Goals (MDGs), then it is continued by Sustainable Development Goals (SDGs) that is currently running. SDGs aim to build and expand the coverage of the MDGs that have ended in the same year when SDGs launched, and this international platform tries to integrate economic and social development with environmental sustainability.

Meanwhile, creating a sustainable city and settlement is one of the important agendas of attention to the formation of SDGs, especially Goal 11 that is to realise urban and residential areas that are inclusive, safe, resilient and sustainable.

\section{MDGs to SDGs}

With the end of the implementation of the MDGs by 2015, the United Nations (UN) as the highest institution in the world continue to invite the members to remain committed to undertaking the development that is globally and implemented locally jointly. The collective agreement was born on 25 September 2015 by the legalisation of documents Transforming our world: the 2030 Agenda for Sustainable Development. Since that time, the MDGs officially replaced by the SDGs. Here will be discussed the differences between both of them, as it can be seen in Table 1.

The mission that promoted by the SDGs is zero percent, this is likely a lesson that drawn from the MDGs where many countries were able to exceed the target which was only 50\%. Furthermore, all countries both developed and developing are eligible to take part in sustainable de- velopment. Meanwhile, regarding formulation process, the MDGs built by elites, compare to SDGs was erected in a way that was more participatory by involving some communities around the world through a survey conducted by the UN and its partner agencies. The survey itself was named Myworld Survey, and it can be accessed by real-time through the site data.myworld2015.org. Last, SDGs offers broader goals than the MDGs, it can be seen from the number of objectives and indicators used to achieve this development program, and there are no housing development issues in the MDGs.

In the implementation, there are many controversies and criticisms against MDGs. Bello and Suleman (2011) identified several problems on MDGs; (i) the methodology is inconsistent and difficult to assess the progress, (ii) indicators of quality data are lacking, (iii) the targets are too ambitious and unrealistic, (iv) some countries and regions made biased by the baseline year, ( $\mathrm{v}$ ) the reports of number of countries riddled with inconsistencies. The MDGs is unfair because of some countries unable to gain the full benefit of MDGs, especially African countries (Clemens and Moss, 2005; Easterly, 2008). On the other hand, Rippin (2013) believed that the MDGs has given the lessons for the stakeholders to formulate any new development concept. Thus, by his weaknesses, the MDGs failed to bring the prosperity to some countries; however, the MDGs succeed to stimulated the new era of the development program which is the Sustainable Development Goals.

Despite the fact that the SDGs is intended to replace the MDGs, it cannot yet be known whether the achievement of the SDGs will surpass the MDGs. Battersby (2016) argued that SDGs presented new goals as well as same gaps. Moreover, SDGs is not a binding agreement, but only voluntary agreements. This can cause harm to the achievement of targets, as the 
Available Online at http://journal.unismuh.ac.id/index.php/otoritas

Otoritas : Jurnal Ilmu Pemerintahan, 8 (1), April, 2018, 47

state may feel more tempted to withhold its commitments (Fitri and Vonda, 2016). Thus, SDGs is not a perfect human product, however, by its comprehensive goals, it is likely that the existence of SDGs will at least mask the weaknesses of the MDGs.

\section{SDGs in Indonesia}

At the end of the program, Indonesia has managed to achieve most of the goals of 49 of the 67 indicators of the MDGs. Nevertheless, according to Bappenas (2016) there are still some achievement targets were not fully achieved, as well as the disparity in attainment of the objectives between provinces is still very broad, among others; (i) poverty reduc- tion which is based on the national poverty line, (ii) an increase in the minimum consumption under $1400 \mathrm{kcal} / \mathrm{capita} /$ day, (iii) a decrease in maternal mortality rate, (iv) countermeasures of HIV/AIDS, (v) water supply and sanitation in the rural area. It is not surprising that Indonesia not entirely successful to implement MDGs because they started ten years late from the baseline year. However, Indonesian government still has an opportunity in SDGs; thus they will be continued to finish the problems that have not been done in MDGs.

And to implement the SDGs in Indonesia, the government appointed the Badan Perencanaan dan Pembangunan Nasional (Bappenas) as coordinator to for-

Table 1. The difference between MDGs and SDGs

Source: Beare (2015)

\begin{tabular}{|c|c|}
\hline MDGs (2000-2015) & SDGs (2015-2030) \\
\hline 50 percent & 100 percent \\
\hline $\begin{array}{l}\text { The goal is half, like halving poverty. Target } \\
\text { tends to bear. The attainment in 2015, } \\
\text { many countries were able to exceed the tar- } \\
\text { get. }\end{array}$ & $\begin{array}{l}\text { The target is to end all forms of social } \\
\text { problems such as hunger and poverty com- } \\
\text { pletely (zero) without the slightest remain- } \\
\text { ing. }\end{array}$ \\
\hline From developed countries to developing & Universally applicable \\
\hline countries & SDGs looked all countries have hor \\
\hline $\begin{array}{l}\text { MDGs posit that poor and developing coun- } \\
\text { tries that have a lot of homework to be } \\
\text { completed. Meanwhile, the developed coun- } \\
\text { tries support the efforts made by these } \\
\text { countries through the provision of funds. }\end{array}$ & $\begin{array}{l}\text { ome. Each } \\
\text { lake policy }\end{array}$ \\
\hline Top-Dow & Bot \\
\hline $\begin{array}{l}\text { MDGs were formulated by the elites (UN } \\
\text { and OECD) without any process of consulta- } \\
\text { tions or meetings and a survey of residents. }\end{array}$ & $\begin{array}{l}\text { The formulation of SDGs is more participa- } \\
\text { tory than MDGs, there was face to face } \\
\text { meetings and attended by more than } 100 \\
\text { countries. Also, there was a citizen survey. }\end{array}$ \\
\hline Parti & Comprehensive solution \\
\hline $\begin{array}{l}\text { The eight purposes of the MDGs were not } \\
\text { comprehensive. Some important issues } \\
\text { such as ecology and environmental were } \\
\text { not getting attention. Likewise the issue of } \\
\text { taxes and the financing of development, and }\end{array}$ & $\begin{array}{l}\text { Contains } 17 \text { objectives which seek to } \\
\text { change the structure and systems. There } \\
\text { are global issues such as; good governance, } \\
\text { social inequality, urban problems, and so } \\
\text { forth. }\end{array}$ \\
\hline
\end{tabular}


Available Online at http://journal.unismuh.ac.id/index.php/otoritas

Otoritas : Jurnal Ilmu Pemerintahan, 8 (1), April, 2018, 48

mulate a Rencana Aksi Nasional (RAN) which can be used as a reference for all stakeholders both at national and regional level. RAN is the five years work plan document for the implementation of various activities that directly and indirectly support the achievement of SDGs that adapts to the national target. Moreover, RAN is expected to be able to build commitment of stakeholders at a national and provincial level to succeed in achieving SDGs in 2030.

To formulate the RAN, the Bappenas integrated the SDGs, as the SDGs has become a reference in the national development programs in Indonesia, with RPJMN 2015-2019 which is the five years planning document for the medium term. RPJM is the third phase of the Rencana Pembangunan Jangka Panjang (RPJP) 2005-2025, and it has been a reference for each ministry/agency and other stake- holders in designing of strategic planning and the work plan in Indonesia. Furthermore, the attainment of SDGs and RPJMN 2015-2019 in RAN have conducted in the form of policy formulation, an establishment of programs/activities, objectives, indicators, and guarantee the provision of funding sources.

SDGs and RPJMN primarily derived from a different perspective, RPJMN designed based on regional issues concerning the welfare and sovereignty of Indonesia, while SDGs centred on global issues related to the continuity of the world that should be followed by all countries. Even though so, substantively, there were no significant contradictions in both the development agenda. Even in chapter 3.4 RPJMN written that the government is ready to bring the national development programme to a global context, which ultimately SDGs mentioned as a reference.

Table 2. RPJMN 2015-2019 and SDGs Reflections

Source: RPJMN 2015-2019 Document

\begin{tabular}{|c|c|c|}
\hline No. & RPJMN 2015-2019 & SDGS \\
\hline 1. & $\begin{array}{l}\text { Bringing back the country to protect the people } \\
\text { and provide security to all citizens. (10 actions) }\end{array}$ & Goals $9-10,13$, and $16-17$ \\
\hline 2. & $\begin{array}{l}\text { Establishing the clean, efficient, democratic, and } \\
\text { reliable governance. ( } 5 \text { actions) }\end{array}$ & Goals 5,10 , and $16-17$ \\
\hline 3. & $\begin{array}{l}\text { Indonesia builds from the periphery to strengthen } \\
\text { the local and the villages within the framework of } \\
\text { a unitary state. ( } 3 \text { actions) }\end{array}$ & Goals 1-12 \\
\hline 4. & $\begin{array}{l}\text { Strengthening the country's presence in reform- } \\
\text { ing the law enforcement system and corruption- } \\
\text { free, dignified and reliable. ( } 6 \text { actions) }\end{array}$ & Goals 5, 10, and 14-16 \\
\hline 5. & $\begin{array}{l}\text { Improving the quality of human life and the socie- } \\
\text { ty in Indonesia. ( } 5 \text { actions) }\end{array}$ & Goals $1-4,6,8$, and 10 \\
\hline 6. & $\begin{array}{l}\text { Improving people's productivity and competitive- } \\
\text { ness in the international market. ( } 11 \text { actions) }\end{array}$ & Goals 8-11, and 17 \\
\hline 7. & $\begin{array}{l}\text { Realising economic independence by moving the } \\
\text { strategic sectors of the domestic economy. ( } 9 \text { ac- } \\
\text { tions) }\end{array}$ & Goals 2, 6-9, and 12-15 \\
\hline 8. & A revolution of national character. (1 action) & Goal 4 \\
\hline 9. & $\begin{array}{l}\text { Strengthening a diversity and cultural restoration } \\
\text { Indonesia. ( } 1 \text { action) }\end{array}$ & Goals 5,10 , and $16-17$ \\
\hline
\end{tabular}


Available Online at http://journal.unismuh.ac.id/index.php/otoritas

Otoritas : Jurnal Ilmu Pemerintahan, 8 (1), April, 2018, 49

However, it should be stressed that the SDGs is not the foreign interests that forced into the national development agenda, it is on the contrary that the SDGs is full accordance with the ideals of national development and bullet point contained in the SDGs is to strengthen RPJMN. Therefore, the SDGs can be easily integrated into the national development agenda. Furthermore, the convergence of the national agenda with the global agenda offers an opportunity for countries to engage internationally and regionally, and the 17 goals of SDGs will provide a platform for a sustainable global partnership and provide benefits to the countries and stakeholders for their participation. And the similarity between SDGs with RPJMN can be seen in table 2 .

The national development agenda is discussed in chapter six of RPJMN 20152019 , there are nine targets that Indonesian government wants to gain in this medium-term, and all of the 17 goals of SDGs are parallel and have been included in nine goals of RPJMN 2015-2019. The table shows that Goal 10 of SDGs (reduced inequalities) is the most severe problem, and it is raising in Indonesia (World Bank, 2016). Thus, it is not surprising that seven of the nine targets contained in RPJMN focuses on reducing inequality. Meanwhile, housing development issue which is the primary concentrate of this essay include two points of RPJMN 2015-2019, those are points 3 and 6 .

Achievement of the target of SDGs has been established through the Presidential Regulation No. 59 of 2017 on the Implementation of the Achievement of Sustainable Development Objectives, while Government Regulation Number 14 the Year 2016 on the Implementation of Housing and Settlement Area is a specific description of the implementation plan of Goal 11. The birth of these two legal products is one a form of seriousness demonstrated by the government towards the realization of SDGs in 2030.

\section{The Million Houses Program}

One of the bases for assessing the quality of life and welfare of communities is housing, and it is also a crucial feature of sustainable development (Golubchikov and Badyina, 2012). As it is known along that the shelter is one of three primary requirements in addition to clothing and food, thus it can be said that the house is an absolute necessity and a prerequisite for prosperity. Unfortunately, not everyone can meet housing needs, and it can happen because of lack of income, so the ability to buy or rent is low, and it also could be due to unavailability of land for building, especially in urban areas.

Housing problems faced in the modern era is more complex than for the time being because there is a shortage of housing supply everywhere around the world. It is estimated that 863 million people currently occupy the slums area, and the number is projected to double by 2030 (Millington and Cleland, 2017). Therefore, urban poverty eradication which has been mandated in SDGs is a major challenge that must be addressed.

In Indonesia, there are still many people who are forced to become homeless which eventually causes them to have to sleep in a place that is not suitable as; under a bridge, riverbank, railroads, and other slum areas. According to the static table of BPS (2017), the percentage of households that have their homes has increased from $78 \%$ in 2010 to $82.63 \%$ in 2015, unfortunately, it decreased to $79.61 \%$ in 2017 . Thus, although there are fluctuations that have resulted in a house ownership declining in the last two years, overall, the percentage of home ownership continues to increase over time.

Meanwhile, according to the data referred to the government, the slums area in Indonesia currently is 38,431 hectares, with details of 23,473 acres in urban areas and 11,957 hectares of the countryside (Pitoko, 2016). The effort to 
Available Online at http://journal.unismuh.ac.id/index.php/otoritas

Otoritas : Jurnal Ilmu Pemerintahan, 8 (1), April, 2018, 50

free the slum areas integrated with the provision of houses for low-income people, and to meet housing needs, the Indonesian government through the Ministry of Public Works and Public Housing has been running the program a million homes since 2015. This program is part of government efforts to succeed the SDGs especially Goal 11, and the following of Table 3 describes the million houses program in RAN.

From the figure, it can be seen that both SDGs and RPJMN have one vision, that is to free the vile area to be a comfortable space for the community to live, and by its power and resources building houses is likely a simple task for government. Despite the fact that building a house is an easy thing for the government, it can be a difficult circumstance to build a home that meets sustainability characteristic.

Sustainability is maintaining the continuity of the human needs for an extended period into the future (Common and Stagl, 2005), and to accomplish a sustainable home there are three aspects of sustainable development that have to consider, namely; environmental, social, and economic (Mignaqui, 2014). Moreover, Golubchikov and Badyina (2012) said that sustainable housing is crucial to be applied for the benefit of the future be- cause it can offer a vast spectrum in promoting economic development, environmental management, improved quality of life and social equality. Thus, the million homes program is a great effort from the government to overcome the shortage of houses and providing the affordable houses for low-income families in Indonesia, but the quantity must be accompanied by quality, that is to build a home which is sustainable. According to Teferi and Newman (2017), the development of policies concerning urban revitalisation currently has been evolving from total clearance and eviction approaches to a laxer, more economically, socially, and environmentally sustainable approach. Thus, nowadays sustainability is a concept that is being warmly discussed and applied by stakeholders.

Discussing those dimension of sustainable more deeply. First, let have a look at environmental sustainability. Environmental aspects of sustainable housing are everything that related to climate change and the environment, and how the environmental impact of the housing itself (Golubchikov and Badyina, 2012). In 2015, about 33 million people live in slums (Agustian, 2015), and that was not a good environmental to live. It has been believed that the are many environmental problems caused by slums, such as the

Table 3. The RAN (Goal 11 of SDGs/Housing Development)

Source: Bappenas (2016)

\begin{tabular}{|c|c|c|c|c|c|}
\hline Target of SDGs & Indicator & $\begin{array}{c}\text { Target of } \\
\text { RPJMN }\end{array}$ & Indicator & $\begin{array}{c}\text { Baseline } \\
(2015)\end{array}$ & $\begin{array}{l}\text { Target } \\
(2030)\end{array}$ \\
\hline $\begin{array}{l}\text { By } 2030, \text { ensure } \\
\text { access for all to ad- } \\
\text { equate housing, } \\
\text { safe, affordable } \\
\text { housing, and essen- } \\
\text { tial services, as well } \\
\text { as organise slum. }\end{array}$ & $\begin{array}{l}\text { The propor- } \\
\text { tion of urban } \\
\text { population } \\
\text { living in } \\
\text { slums, infor- } \\
\text { mal settle- } \\
\text { ments or } \\
\text { house that is } \\
\text { not feasible. }\end{array}$ & $\begin{array}{l}\text { Achieving } \\
\text { a reduc- } \\
\text { tion of } \\
\text { urban } \\
\text { slum area }\end{array}$ & $\begin{array}{l}\text { Regional } \\
\text { urban } \\
\text { slums }\end{array}$ & 38,431 ha & ha \\
\hline
\end{tabular}


Available Online at http://journal.unismuh.ac.id/index.php/otoritas

Otoritas : Jurnal Ilmu Pemerintahan, 8 (1), April, 2018, 51

sanitation and drainage which are not in a healthy functioning, as well as the waste that has not been managed properly, and others environmental problems. Then these conditions provide a source of pollution which eventually led to the root of the spread of diseases. Moreover, as has been mentioned earlier that recently the slum areas in Indonesia is 38,431 acres, and approximately 2,562 hectares have to be alleviated annually to meet the realisation of SDGs that is zero percent in 2030. Thus, the million housing project which likely to apply environmental sustainability will be able to be a bridge to overcome the environmental problems that are nearby, as is the case with public health, energy efficiency, water and sanitation, waste management and recycling, green spaces, and others environmental mitigation measures.

Second, providing low-cost housing with high quality, inclusive and diverse (mixed-tenure and mixed-income), healthy, safe and comfortable, and wellintegrated into the broader socio-spatial are the characteristics of social sustainability (Golubchikov and Badyina, 2012). According to Kemempupera (2016), the million houses program aim to build one million units annually, with details of 700,000 units specifically earmarked for low-income people, and 300,000 units for non-low income. Thus, the of purposes of the million houses program is to provide the low-cost housing for low-income people, and also there are some units traded for commercial needs, so it is not only affordable but also inclusive and diverse which mean that this program represents social aspects of sustainability.

However, this program has the potential of social risks which is the emergence of social jealousy between beneficiaries and non-beneficiaries caused by inaccuracy target recipients of the program, especially for those who are entitled to a house but not included in the list of the beneficiaries. Moreover, it is a fact that Indonesian government have bad experience in delivering a program, and some previous experience shows there was an imprecision target in allocating social assistance, for example, rice for the poor program; that there were still some people who were not entitled to be beneficiaries of this social program (World Bank, 2012). Of course, the case should be a lesson for the government to run the program as accurately as possible. So the million homes program will be thoroughly enjoyed by low-income people.

The last is economic dimensions of sustainability. Everything that related to the functioning of housing will have implications on the operation of the economy, such as standards of productivity and human mobility; standard household expenditure and public spending; platform of economic activity and the primary field of work; and part of the natural resources and energy flow (Golubchikov and Badyina, 2012). The million houses program is likely as the economic locomotive which will run others economic activities. First, this housing construction needs worker; thus it will take a lot of employees with different skills to fill some positions needed. Second, this housing development will open a great opportunity for a private investor to invest the funds that will become profitable for them. Third, the wheels of the economy will be faster, seeing the needs of construction goods will increase, then when ready for the habitation of the occupants require some new household furniture. And others economic benefits. Moreover, as it is mainly targeted for low-income families, the affordable price is required.

Tibaijuka (2009) said that affordable housing is seen as a primary instrument of social welfare because it can reduce poverty, create justice, and guarantee the rights of the housing. Moreover, the most important thing that affordable housing can provide is; it can present all three dimensions of the sustainability aspect, and 
Available Online at http://journal.unismuh.ac.id/index.php/otoritas

Otoritas : Jurnal Ilmu Pemerintahan, 8 (1), April, 2018, 52

this can also affect the 13 goals set in the SDGs out of 17 goals directly and indirectly (UN, 2014). Thus, affordable housing is a productive asset which has a significant contribution to the national welfare and economic development.

Nevertheless, since running in 2015, the million houses program unfortunately never caught one million units, only 699,770 units in 2015 and 805,169 units in 2016 (Pitoko, 2017). According to Caiserio (2016), at least there are seven main challenges faced currently by the government in order to realise a million homes program, namely; (i) the housing data are less accurate; (ii) the program has not been well communicated to stakeholders in the region; (iii) the housing is not a major program of local government; (iv) the local government regulations relating to the construction house/residential not yet supported; (v) housing construction licencing in the form of requirements and permit issuance process is complicated; (vi) the land prices are expensive and limited, (vii) the high requirements of mortgages by Bank of Indonesia. By those huge obstacles, it is not surprising that the government unable to realise one million units annually, however, there is an increasing number from 2015 to 2016 which shows that there is a sight of progress in the effort to achieve the one million target annually. Moreover, the government still have a long time to realise the goal, and it is likely the program will meet the objective at the end of the program if the government improve their performance by fix the data accuracy, build a better communication to local authorities and the bank, and also controlling the land price. Thus, the zero poverty is likely will be achieved in 2030 .

\section{CONCLUSION}

There is an exclusion of economic and environmental aspects in the MDGs, and it too relies on social development issues only, such as poverty, health, and education. The imbalances of development become a shortage of MDGs, and SDGs present to balance the development plan by integrating the three dimensions (social, economic, and environmental) as well which eventually became the three top pillars of sustainable development. Moreover, SDGs was born through an open process, and it applies universally that makes all nations have a chance to develop.

Indonesia has gained valuable experience in the implementation of the global agenda such as the MDGs into their national policies, of course, it can be easier for the government to re-adopt the world program such as SDGs. Convergence is happening between SDGs and RPJMN, and it represents the union of global objectives that have been reflected in the national agenda. This convergence has been integrated explicitly into national policies and regional levels as well.

The million houses program is an excellent program to help low-income families to have their own homes, and it also supports the sustainable development as long as it meets environment, social, and economic aspects. Unfortunately, the government unable to achieve a million target annually. However, it will be better if the government focus more on quality which is applying sustainability concept to the program rather than quantity which is pursuing millions target annually. Therefore, the Success of this program is likely will depend on the political willingness of the government and community participation in the long term. However, regardless of its obstacles, it still a long way to go for the government to deal with the complications and objectify the program in 2030.

\section{ACKNOWLEDGEMENT}

I Sincerely thank to LPDP RI for providing me with the financial support during my study andresearch at University of Glasgow. 
Available Online at http://journal.unismuh.ac.id/index.php/otoritas

Otoritas : Jurnal Ilmu Pemerintahan, 8 (1), April, 2018, 53

\section{REFERENCES}

Andrews, L., et al. (2012) Classic Grounded Theory to Analyse Secondary Data: Reality and Reflections. The Grounded Theory Review, Volume 11, pp. 12-26.

Agustian, W. (2015) 33 Million Population Living in Slum Areas. Okezone [Online]. Available from: <https://goo.gl/GEqKjB>

[Accessed 8 April 2017].

Bappenas. (2015) Development Planning Documents. Bappenas [Online]. Available from: <https://goo.gl/ Ebz8sg> [Accessed 28 March 2017].

Bappenas. (2016) Zero Draft: Technical Guidelines for Sustainable Development Action Plan. The Secretariat of SDGs Indonesia [Online]. Available from: <https://goo.gl/ FC98by> [Accessed 28 March 2017].

Battersby, J. (2017) MDGs to SDGs-new goals, same gaps: the continued absence of urban food security in the post-2015 global development agenda. African Geographical Review, Volume 36 (1), pp.115-129.

Bello, A. and Suleman, A. (2011). The Challenge of Achieving the Millennium Development Goals in IDB Member Countries in the PostCrisis World. ISDB. [online] Available at: <https://goo.gl/jev7go> [Accessed 10 April 2017].

Beare, K. (2015) From MDGs to SDGs: What's Different? Feelgood
[Online]. Available from: <https://goo.gl/xJTRph> [Accessed 28 March 2017].

BPS. (2017) Static Table: Housing Indicators 1993-2017. Badan Pusat Statistik [Online]. Available from: <https://goo.gl/X8dStm> [Accessed 29 March 2017].

Caiserio, E.B. (2016) The Following is the Obstacles of the Million Houses Program. Properti [Online]. Available from: <https://goo.gl/giAGnv> [Accessed 16 April 2017].

Clemens, M. and Moss, T. (2008). What's Wrong with the Millennium Development Goals. CGDEV. [online] Available at: <https://goo.gl/ 11WC1a> [Accessed 10 April 2017].

Common, M., and Stagl, S. (2005) Ecological Economics: An Introduction. Cambridge: Cambridge University Press.

Easterly, W. (2008). How the Millennium Development Goals are Unfair to Africa. World Development, 37(1), pp. 26-35.

Fitri, C., and Vonda, P. (2016) How the Commitment to Achieve Sustainable Development Goals Impacts Poor Women in Aceh Province, Indonesia. Gender Equality: International Journal of Child and Gender Studies, Volume 2 (2), pp.5158.

Golubchikov, O., and Badyina, A. (2012) Sustainable Housing for Sustainable Cities: A Policy Framework for 
Available Online at http://journal.unismuh.ac.id/index.php/otoritas

Otoritas : Jurnal Ilmu Pemerintahan, 8 (1), April, 2018, 54

Developing Countries. Nairobi: UN-HABITAT.

Johnston, M.P. (2014). Secondary Data Analysis: A Method that which a Time Has Come. Quantitative and Qualitative Methods in Library (QQML), Volume 3, pp. 619-626.

Kemenpupera. (2016) Ministry PUPR to Build 700,000 Unit Homes for Low-Income Communities in 2016. Kemepupera [Online]. Available from: <https:// goo.gl/5XibFx> [Accessed 9 April 2017].

Kumar S. et al. (2016). Millennium Development Goals (MDGs) to Sustainable Development Goals (SDGs): Addressing Unfinished Agenda and Strengthening Sustainable Development and Partnership. Indian J Community Med, Volume 4, pp.1-4.

Lubis, E. and Sinaga, A. (2018) Legal Perspective of Using Philanthropy Approach for Low Income Household in Accessing Sufficient House in Indonesia. Sriwijaya Law Review, volume 2(1), p.93-109.

Mignaqui, V. (2014) Sustainable Development as a Goal: Social, Environmental and Economic Dimensions. International Journal of Social Quality, volume 4(1), 2014, p. 57-77.

Millington, K.A., and Cleland, J. (2017) Counting people and making people count: Implications of future population change for sustainable development, K4D Helpdesk Re- port. Brighton, UK: Institute of Development Studies.

Pitoko, R.A. (2016) Note, the Indonesian Slum Area More than 38,000 Hectares. Kompas [Online]. Available from: <https://goo.gl/mRLhky> [Accessed 29 March 2017].

Pitoko, R.A. (2017) Basuki Optimists that the Million Houses Program Will Achieved the Target in this Year. Kompas [Online]. Available from: <https://goo.gl/HBSW8z> [Accessed 29 March 2017].

Rippin, N. (2013). Progress, Prospects, and Lessons from the MDGs. Highlevel Panel. [online] Available at: <https://goo.gl/4Er2Ji> [Accessed 10 April 2017].

Susanti, R. et al. (2016) Smart Growth, Smart City and Density: in Search of the Appropriate Indicator for Residential Density in Indonesia. Procedia-Social and Behavioral Sciences, volume 227, p.194-201

Teferi, Z., and Newman P. (2017) Slum Regeneration and Sustainability: Applying the Extended Metabolism Model and the SDGs. Sustainability, Volume 9, pp.1-16.

Tibaijuka, A.K. (2009) Building Prosperity: Housing and Economic Development. London: Earthscan.

United Nations. (2014) Major Groups and other Stakeholders Morning Hearings: Summary of Statements. United Nations [Online]. Available from: <https://goo.gl/wH2EgM> [Accessed 02 January 2018]. 
Available Online at http://journal.unismuh.ac.id/index.php/otoritas

Otoritas : Jurnal Ilmu Pemerintahan, 8 (1), April, 2018, 55

United Nations. (2015) Transforming our World: The 2030 Agenda for Sustainable Development. United Nations [Online]. Available from: <https://goo.gl/RsCfjC> [Accessed 22 March 2017].

World Bank. (2012) Raskin Subsidized Rice Delivery, Social Assistance
Program and Public Expenditure Review 3 [Online]. Available from: <https://goo.gl/2jQURY> [Accessed 1 April 2017].

World Bank. (2016) Indonesia's Rising Divide [Online]. Available from: <https://goo.gl/dVyp9R> [Accessed 10 April 2017]. 